\title{
Are we really preventing lung collapse with APRV?
}

\author{
Ryota Sato $^{1^{*}}$ (D) Natsumi Hamahata ${ }^{1}$ and Ehab G. Daoud ${ }^{1,2,3}$ \\ This comment refers to the article available at https://doi.org/10.1186/s13054-018-2051-8.
}

Keywords: Airway pressure release ventilation, APRV, Trans-pulmonary pressure, Esophageal balloon

Letter to the editor

APRV is an inverse ratio, pressure-controlled, intermittent mandatory ventilation without the restriction of spontaneous breathing, and it is based on the principle of the open-lung approach [1]. A recent meta-analysis reported beneficial effects of APRV on ventilator-free days and in-hospital mortality in acute hypoxic respiratory failure; however, the quality of evidence was low [2]. Therefore, it has been still controversial whether APRV is truly beneficial or not.

The main settings of APRV include $P_{\text {High }}, P_{\text {Low }}, T_{\text {High }}$, and $T_{\text {Low }}$. There are numerous suggested ways for setting $T_{\text {Low }}$ to prevent alveolar collapse, e.g., setting $T_{\text {Low }}$ to create auto-PEEP empirically in a range of $0.2-0.8 \mathrm{~s}$ or to achieve $50-75 \%$ of peak expiratory flow or according to a certain time constant, and for a certain volume per release [1]. However, it has been unclear whether APRV truly stabilizes the alveoli and reduces lung stress and strain [3] since it is uncertain how much auto-PEEP we are creating and whether it is enough to prevent alveolar collapse especially in the setting of elevated alveolar elastance.

The measurement of trans-pulmonary pressure $\left(P_{\mathrm{TP}}\right)$ using an esophageal balloon is a physiological way to detect and prevent lung stress and strain. Using that strategy has shown improved oxygenation and compliance, and trend towards improved mortality [4].

Recently, we reported that $P_{\mathrm{TP}}$ in patients undergoing APRV was in the negative values $\left(<0 \mathrm{cmH}_{2} \mathrm{O}\right)$ at all levels $(0.1$ to $0.8 \mathrm{~s})$ of $T_{\text {Low }}$ suggesting the alveolar collapse but was actually positive after the application of an

\footnotetext{
* Correspondence: st051035@gmail.com

${ }^{1}$ Department of Internal Medicine, John A. Burns School of Medicine,

University of Hawaii at Manoa, 1356 Lusitana Street, 7th floor, Honolulu, HI

96813, USA

Full list of author information is available at the end of the article
}

end-expiratory occlusion maneuver to measure total and auto-PEEP (the gold standard for measuring total PEEP) [5]. This case report demonstrates a new method to adjust $T_{\text {Low }}$, also highlights the need to quantify the actual total PEEP at the end of $\mathrm{T}_{\mathrm{Low}}$, and enforces the beneficial knowledge gained by esophageal balloon in APRV. The expiratory flow decay and the resultant auto-PEEP during APRV are variable among different ventilator manufacturer [1], and using a time constant may not be reliable as well. Recently, it was suggested that the use of tracheal pressure at the end of $T_{\mathrm{Low}}$ as the amount of auto-PEEP might not be accurate either [3].

In conclusion, without the knowledge of end release trans-pulmonary pressure, we are driving blind not knowing how often we are causing alveolar collapse with APRV. Therefore, there is an emergent need for more research about its settings given its rising popularity.

\section{Abbreviations}

APRV: Airway pressure release ventilation; Auto-PEEP: Intrinsic PEEP;

PEEP: Positive end-expiratory pressure; PEF: Peak expiratory flow; $P_{\text {High }}$ : The value of the high pressure (inspiratory pressure); $P_{\text {Low: }}$ : The value of the low pressure (release pressure); $P_{\mathrm{TP}}$ : Trans-pulmonary pressure; $T_{\text {High }}$ : Time spent at high-pressure phase; $T_{\text {Low: }}$ : Time spent at low-pressure phase

\section{Acknowledgements}

Not applicable

\section{Funding}

None

\section{Availability of data and materials} Not applicable

\section{Authors' contributions}

RS and ED were responsible for the conception of the letter. All authors drafted the manuscript. All authors read and approved the final manuscript.

\section{Authors' information}

$\mathrm{RS}$ and $\mathrm{NH}$ are internal medicine residents in the USA. ED is a board-certified intensivist in the USA. 
Ethics approval and consent to participate

Not applicable

\section{Consent for publication}

Not applicable

\section{Competing interests}

The authors declare that they have no competing interests.

\section{Publisher's Note}

Springer Nature remains neutral with regard to jurisdictional claims in published maps and institutional affiliations.

\section{Author details}

'Department of Internal Medicine, John A. Burns School of Medicine, University of Hawaii at Manoa, 1356 Lusitana Street, 7th floor, Honolulu, HI 96813, USA. ${ }^{2}$ Respiratory Care Program, Kapiolani Community College, Honolulu, HI, USA. ${ }^{3}$ Critical Care Department, Kuakini Medical Center, Honolulu, HI, USA.

Received: 21 April 2019 Accepted: 1 May 2019

Published online: 16 May 2019

\section{References}

1. Daoud EG, Farag HL, Chatburn RL. Airway pressure release ventilation: what do we know? Respir Care. 2012;57(2):282-92.

2. Carsetti A, Damiani E, Domizi R, Scorcella C, Pantanetti S, Falcetta S, Donati A, Adrario E. Airway pressure release ventilation during acute hypoxemic respiratory failure: a systematic review and meta-analysis of randomized controlled trials. Ann Intensive Care. 2019;9(1):44.

3. Nieman GF, Andrews P, Satalin J, Wilcox K, Kollisch-Singule M, Madden M, Aiash H, Blair SJ, Gatto LA, Habashi NM. Acute lung injury: how to stabilize a broken lung. Critical Care (London, England). 2018;22(1):136.

4. Talmor D, Sarge T, Malhotra A, O'Donnell CR, Ritz R, Lisbon A, Novack V, Loring $\mathrm{SH}$. Mechanical ventilation guided by esophageal pressure in acute lung injury. N Engl J Med. 2008;359(20):2095-104.

5. Daoud EG, Yamasaki KH, Nakamoto K, Wheatley D. Esophageal pressure balloon and transpulmonary pressure monitoring in airway pressure release ventilation: a different approach. Can J Respir Ther. 2018;54(3):1-4.

- fast, convenient online submission

- thorough peer review by experienced researchers in your field

- rapid publication on acceptance

- support for research data, including large and complex data types

- gold Open Access which fosters wider collaboration and increased citations

- maximum visibility for your research: over $100 \mathrm{M}$ website views per year

At $\mathrm{BMC}$, research is always in progress.

Learn more biomedcentral.com/submissions 